\title{
PENINGKATAN KEMAMPUAN PENALARAN MATEMATIS MAHASISWA PENDIDIKAN GURU MADRASAH IBTIDAIYAH MELALUI CONCEPT ATTAINMENT MODEL
}

\author{
Mimi Hariyani, Zubaidah Amir MZ \\ Prodi PGMI Fakultas Studi Islam \\ Universitas Islam Negeri Sultan Syarif Kasim Riau \\ e-mail: zubaidah.amir@uin-suska.ac.id
}

Naskah diterima : 25 Februari 2018, direvisi : 29 Maret 2018, disetujui : 23 April 2018

\begin{abstract}
This study aims to find out the improvement of mathematical reasoning ability of the students of Madrasah Ibtidaiyah (PGMI) Teachers who gain learning with Concept Attainment Model (CAM) and analyze student attitude toward learning. This model consists of the data presentation stage, the concept achievement testing stage, and the analytical stage of thinking strategy. The study was conducted with stages in the lesson study based learning, consisting of 3 cycles according to the time allocation and the chosen subject. Each cycle consists of plan, do and see. This research involves students of PGMI Program Faculty of Tarbiyah and Teacher Training UIN Suska Riau, in April-June 2017 in the course of the Numbers System. The population numbered 101 people and the sample was taken from local B which amounted to 35 people. Data were collected using questions of mathematical reasoning skills, observation sheets, attitude scales, and interviews. Attitude-scale data, observation sheets, and interview results were analyzed descriptively, while test data were analyzed with normalized NGains and classified according to category, height: $\% \mathrm{~g}>70$, moderate: $30 \leq \% \mathrm{~g} \leq 70$, and low: $\% \mathrm{~g}<30$. The results showed an increase in students' mathematical reasoning abilities after following CAM lessons. This increase can be seen from normalized gain percentage, that is from 35 students, there are 21 people $(60 \%)$ in high category, 14 people $(40 \%)$ in medium category, and no student in low category. This is also supported by the results of open observation, that learning activities with CAM can be done well during the study took place. Based on the results of data analysis of attitude scores and interview results showed that most students have a positive attitude towards learning with CAM. This model can be varied with other learning such as cooperative learning, metacognitive approach, etc. and can be tested at the level of school students both basic and middle level
\end{abstract}

Keywords: Mathematical Reasoning ability, Concept Attainment Model

Pengutipan: Mimi Hariyani, Zubaidah Amir MZ. (2018). Peningkatan Kemampuan Penalaran Matematis Mahasiswa Pendidikan Guru Madrasah Ibtidaiyah melalui Concept Attainment Model JMIE: Journal of Madrasah Ibtidaiyah Education, 2(1), 2018, 119-130. jmie.v2i1.58. 


\section{PENDAHULUAN}

Kemampuan-kemampuan matematis yang harus dimiliki oleh siswa pada jenjang pendidikan dasar dan menengah, juga harus dimiliki oleh mahasiswa calon guru yang akan mengajarkan matematika. Committee on the Undergraduate Program in Mathematics (CUPM) (MAA, 2004) memberikan enam rekomendasi dasar untuk jurusan, program, dan mata kuliah dalam matematika. Salah satu rekomendasinya menerangkan bahwa setiap mata kuliah dalam matematika hendaknya merupakan aktivitas yang akan membantu mahasiswa dalam pengembangan analitis, penalaran kritis, pemecahan masalah, dan keterampilan komunikasi. Rekomendasi CUPM di atas menerangkan bahwa tugas lembaga pendidikan yang bertugas mendidik calon guru yang akan mengajarkan matematika, diantaranya adalah mempersiapkan mahasiswa-mahasiswinya untuk memiliki kemampuan penalaran matematis. termasuk dalam hal ini program studi Pendidikan Guru Madrasah Ibtidaiyah (PGMI) sebagai salah satu lembaga pencetak calon guru MI harus mempersiapkan mahasiswanya dalam kemampuan matematis, termasuk dalam kemampuan penalaran.

Turmudi (2008:7) mengemukakan bahwa kemampuan penalaran matematis adalah kemampuan mengungkapkan argumen yang sangat esensial untuk memahami matematika. Penalaran matematis merupakan proses yang selalu berlangsung dalam pikiran yang harus dikembangkan secara konsisten dengan menggunakan berbagai macam konteks. Artinya penalaran matematis adalah kemampuan untuk menganalisis situasi matematis yang berlangsung, kemudian hasil dari proses menganalisis tersebut mencapai sebuah kesimpulan yang konkrit. Penalaran merupakan proses berpikir yang menghubung-hubungkan fakta-fakta yang diketahui menuju kepada suatu kesimpulan (Keraf, 1982: 5). Shurter dan Piere (Sumarmo, 1987) mendefinisikan penalaran sebagai proses penarikan kesimpulan logis berdasarkan fakta dan sumber yang relevan. Berdasarkan dua pendapat di atas dapat disimpulkan bahwa kemampuan penalaran diperlukan untuk dapat memperoleh suatu kesimpulan berdasarkan fakta-fakta yang ada sebelum mengambil keputusan.

Penalaran matematis merupakan salah satu kemampuan yang diharapkan untuk dimiliki mahasiswa dalam belajar matematika (NCTM, 2000). Russel (1999) mengungkapkan bahwa penalaran matematis merupakan komponen penting dalam pembelajaran matematika dan merupakan alat untuk memahami abstraksi. Jones (1999) NCTM (2000) berpendapat bahwa penalaran matematis merupakan fondasi dalam memahami dan melakukan matematika. Artzt dan Yaloz (1999) mengungkapkankan bahwa penalaran matematis merupakan bagian integral dari pemecahan masalah. Jika dikaitkan dengan berpikir, maka penalaran matematis merupakan komponen utama dari berpikir yang terkadang melibatkan pembentukan 
generalisasi dan menggambarkan konklusi yang valid tentang ide dan bagaimana ideide itu dikaitkan

Hasil studi pendahuluan terhadap sejumlah mahasiswa PGMI yang telah mengikuti perkuliahan konsep dasar matematika di semester ganjil tahun ajaran 2016/2017 menunjukkan rendahnya kemampuan penalaran matematis mahasiswa, hal ini ditunjukkan dari hasil UTS dan UAS mahasiswa yang telah mengikuti perkuliahan konsep dasar matematika selama satu semester, dimana soal UTS dan UAS itu dirancang untuk mengukur kemampuan penalaran matematis mahasiswa. Mahasiswa yang mengikuti UTS dan UAS mata kuliah konsep dasar matematika sebanyak 101 mahasiswa, namun 64 orang diantara mereka mendapat skor di bawah 70, sehingga hasil akhir yang diperoleh rata-rata mendapatkan nilai C. Berdasarkan pengalaman peneliti selama mengajar di program studi PGMI, selama proses pembelajaran berlangsung mahasiswa cenderung kurang aktif dalam pembelajaran, pemahaman mahasiswa akan konsep yang diajarkan masih lemah, komunikasi yang terjadi satu arah, serta kemampuan berpikir atau penalaran matematis mahasiswa masih rendah.

Indikasi rendahnya kemampuan penalaran matematis pada mahasiswa dikemukakan oleh Armiati (2011). Menurut Armiati, rendahnya kemampuan penalaran matematis disebabkan oleh kegiatan perkuliahan yang kurang efektif, bahkan tidak jarang perkuliahan hanya berlangsung satu arah saja. Pembelajaran seperti ini sudah tidak relevan lagi dengan tujuan pembelajaran yang diharapkan.

Concept Attainment Model (CAM) adalah suatu model pembelajaran yang bertujuan untuk membantu mahasiswa memahami suatu konsep tertentu (Uno, 2008: 10). Model pembelajaran ini dapat diterapkan untuk semua umur, dari anak-anak sampai orang dewasa. Model pembelajaran ini lebih tepat digunakan ketika penekanan pembelajaran lebih dititikberatkan pada pengenalan konsep baru, sehingga dapat melatih kemampuan berpikir induktif, melatih kemampuan berpikir analisis, kritis, kreatif dan lain-lain. Bruner (Uno, 2006: 12) mengusulkan teorinya yang disebut free discovery learning. Menurut teori ini, "proses belajar akan berjalan dengan baik dan kreatif, jika dosen memberi kesempatan kepada mahasiswa untuk menemukan suatu aturan (termasuk konsep, teori, definisi, dan sebagainya) melalui contoh-contoh yang menggambarkan (mewakili) aturan yang menjadi sumbernya, dengan kata lain, mahasiswa dibimbing secara induktif untuk memahami suatu kebenaran umum. dalam model ini, terjadi analisis berpikir, yaitu mengungkapkan pikirannya dan berdiskusi antara mahasiswa dan dosen, sesama mahasiswa dalam menemukan konsep.

Berdasarkan latar belakang di atas, maka peneliti melakukan riset dengan tujuan untuk menelaah dan mendeskripsikan peningkatan dan pencapaian kemampuan penalaran matematis mahasiswa Pendidikan Guru Madrasah Ibtidaiyah yang 
memperoleh pembelajaran dengan CAM, (2) Untuk melihat sikap mahasiswa terhadap pembelajaran dengan CAM.

\section{METODE PENELTTAN}

Penelitian ini dilaksanakan di Program Studi Pendidikan Guru Madrasah Ibtidaiyah Fakultas Tarbiyah dan Keguruan UIN Suska Riau pada mata kuliah Sistem Bilangan, tepatnya pada mahasiswa semester dua lokal B. Waktu pelaksanaan pada perkuliahan semester genap tahun akademik 2016/2017.

Prosedur penelitian ini menggunakan metode pengembangan. Sistem pembelajaran yang diterapkan adalah kson yang pelaksanaannya berlangsung dalam 3 siklus yang disesuaikan dengan alokasi waktu dan pokok bahasan yang dipilih. Setiap siklus terdiri dari 3 kegiatan, yaitu : 1) Perencanaan (plan) ; 2) Pelaksanaan dan Observasi (do); 3) Refleksi (see).

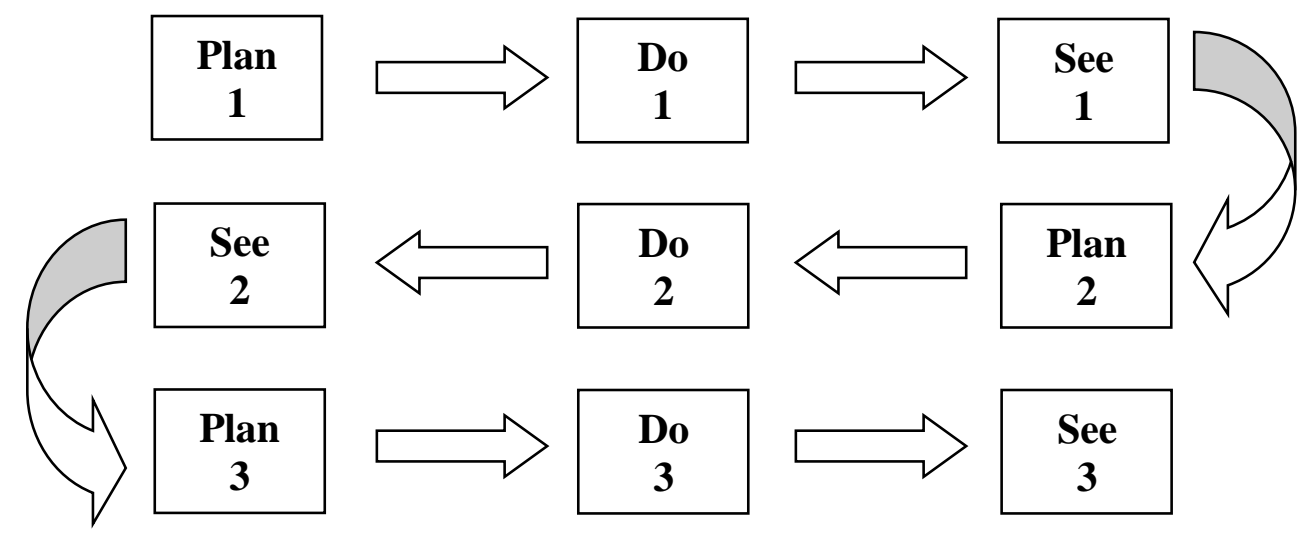

Gambar 1. Prosedur Penelitian

Populasi penelitian ini adalah seluruh mahasiswa semester genap tahun akademik 2016/2017 PGMI UIN Suska Riau yang mengambil mata kuliah Sistem Bilangan yang berjumlah 101 orang. Karena tidak mungkin mempelajari semua yang ada pada populasi, maka peneliti menggunakan sampel yang diambil dari populasi. Penentuan sampel dilakukan dengan cara purposive sampling, yaitu teknik pengambilan sampel berdasarkan pertimbangan tertentu (Sugiyono, 2010). Peneliti memilih mahasiswa PGMI IIB yang berjumlah 35 orang sebagai sampel karena peneliti mengajar di kelas tersebut pada mata kuliah Sistem Bilangan di semester genap tahun ajaran 2016/2017 sehingga memungkinkan untuk bisa lebih fokus dalam melaksanakan penelitian lesson study.

Pelaksanaan lesson study menggunakan satu orang dosen model/praktek yang mengampu mata kuliah Sistem Bilangan, dalam hal ini peneliti sendiri yang menjadi dosen 
model. Selama pelaksanaan, dosen model diamati oleh beberapa orang dosen (observer), yang berasal dari rumpun ilmu matematika.

Secara rinci, penelitian ini diawali dengan pemberian pretest sebelum pembelajaran dengan $C A M$ dimulai. Selanjutnya selama proses pembelajaran observer melakukan pengamatan terkait keterlaksanaan proses pembelajaran menggunakan model pembelajaran $C A M$. Setelah penerapan model pembelajaran $C A M$ berakhir, maka dosen model melakukan posttest. Pelaksanaan pretest dan posttest bertujuan untuk mengukur kemampuan penalaran matematis awal dan kemampuan penalaran matematis akhir mahasiswa.

Pengumpulan data dilakukan dengan teknik tes, observasi, angket dan wawancara. Teknik tes dilakukan untuk mengetahui kemampuan penalaran matematis mahasiswa dalam pembelajaran CAM. Observasi dilakukan terhadap dosen model untuk melihat keterlaksanaan model pembelajaran CAM. Sedangkan angket dan wawancara digunakan untuk melihat sikap mahasiswa terhadap pembelajaran dengan CAM. Instrumen yang digunakan dalam penelitian ini meliputi: tes kemampuan penalaran matematis, lembar observasi terbuka, angket skala sikap dan pedoman wawancara.

Data di analisis secara deskriptif, dengan persentase, menggunakan rumus N-Gain, serta kategorisasi untuk kemampuan penalaran matematis. Persentase gain ternormalisasi setiap mahasiswa dihitung dengan rumus yang dikembangkan oleh hake (1998):

$$
g=\frac{S_{\text {post }}-S_{\text {pre }}}{S_{\text {max }}-S_{\text {pre }}} \times 100 \%
$$

Keterangan: $\mathrm{g}=$ persentase gain ternormalisasi, $\mathrm{S}_{\text {post }}=$ skor tes akhir, $\mathrm{S}_{\text {pre }}=$ skor tes awal, dan $\mathrm{S}_{\max }=$ skor maksimum.

Kriteria peningkatan kemampuan penalaran matematis mahasiswa sesuai kategori, tinggi: $\% \mathrm{~g}>70$, sedang: $30 \leq \% \mathrm{~g} \leq 70$, dan rendah: $\% \mathrm{~g}<30$.

\section{HASIL PENELITIAN DAN PEMBAHASAN}

Sebelum dilakukannya model pembelajaran concept attainment model, terlebih dahulu dilakukan pretest terhadap kemampuan penalaran matematis mahasiswa. Hasil analisis data pretest mahasiswa menunjukkan bahwa nilai kemampuan penalaran matematis mahasiswa PGMI berada di interval 20-67. Dari 35 mahasiswa yang dijadikan objek penelitian, diperoleh hanya 9 orang (33\%) yang mendapatkan nilai $\geq 50$, sedangkan 18 orang (67\%) mendapat nilai < 50. Data ini menunjukkan bahwa kemampuan penalaran matematis mahasiswa PGMI masih rendah. Oleh sebab itu, perlu dilakukannya lesson study dalam rangka meningkatkan kemampuan penalaran matematis. Tabel berikut menjelaskan data pretes kemampuan penalaran matematis mahasiswa sebelum pemberian CAM. 
Tabel 1. Data Pretest Kemampuan Penalaran Matematis Mahasiswa

\begin{tabular}{ccc}
\hline Kategori & Jumlah & Persentase \\
\hline $\mathrm{N}>50$ & 9 & $33 \%$ \\
$\mathrm{~N}<50$ & 18 & $57 \%$ \\
\hline
\end{tabular}

Pembelajaran dengan menggunakan $C A M$ memberikan pengaruh yang baik pada kemampuan penalaran matematis mahasiswa PGMI, hal ini terbukti dari perolehan rata-rata keseluruhan kemampuan penalaran matematis yang diperoleh pada saat posttest lebih tinggi dibanding rata-rata kemampuan penalaran matematis yang diperoleh pada saat pretest. Rata-rata ini diambil dari hasil penormalan (gain ternormalisasi) data kemampuan penalaran matematis mahasiswa PGMI, dimana dari 35 orang mahasiswa, terdapat 21 orang mahasiswa $(60 \%)$ berada pada kategori tinggi dan sebanyak 14 orang mahasiswa (40\%) berada pada kategori sedang. Tidak ada mahasiswa yang berada pada kategori rendah. Data dapat dilihat pada tabel 2 berikut:

\section{Tabel 2.}

Data Kategorisasi Kemampuan Penalaran Matematis Mahasiswa berdasarkan N-Gain

\begin{tabular}{ccc}
\hline Kategori & Jumlah & Persentase \\
\hline Tinggi & 21 & $60 \%$ \\
Sedang & 14 & $40 \%$ \\
Rendah & 0 & $0 \%$ \\
\hline
\end{tabular}

Hal ini juga didukung oleh data hasil observasi selama pembelajaran. Aktivitas yang diamati dalam pembelajaran sesuai dengan langkah-langkah pembelajaran dengan $C A M$, yaitu: (1) Dosen menyajikan data kepada mahasiswa, setiap data merupakan contoh dan bukan contoh yang terpisah, kemudian mahasiswa diminta untuk memberi nama konsep tersebut, dan menjelaskan definisi konsep berdasarkan ciri-cirinya; (2) Mahasiswa menguji perolehan konsep mereka dengan cara mengidentifikasi contoh tambahan lain yang mengacu pada konsep tersebut, dan memunculkan contoh mereka sendiri; (3) Mahasiswa diminta untuk menganalisis atau mendiskusikan strategi yang mereka gunakan sampai mereka dapat menemukan konsep tersebut. Berdasarkan hasil observasi, diperoleh data bahwa aktivitas pembelajaran dengan $C A M$ dapat terlaksana dengan baik selama penelitian berlangsung. Meskipun pada pertemuan-pertemuan awal terdapat beberapa kendala, 
namun kendala-kendala tersebut dapat diatasi dan terus dilakukan perbaikan pada tahap refleksi di setiap akhir siklus.

Sikap mahasiswa terhadap pembelajaran dengan CAM yang dianalisis adalah minat terhadap pembelajaran dengan CAM, minat terhadap belajar kelompok, dan minat terhadap pembelajaran menggunakan Lembar Kerja Mahasiswa. Berdasarkan angket, terlihat bahwa sikap mahasiswa secara keseluruhan terhadap pembelajaran dengan CAM dalam kelompok kecil adalah positif. Hal ini dapat dilihat dari besarnya persentase mahasiswa yang memilih item setuju pada pernyataan positif "Cara belajar yang baru ini memberikan kesempatan saya berpikir" yaitu sebanyak 14 orang mahasiswa atau 40\% dan sangat setuju sebanyak 20 orang mahasiswa atau 57\%. Pada pernyataan positif "Dengan pembelajaran ini, materi Sistem Bilangan yang dipelajari lebih mudah dipahami dengan baik" yaitu sebanyak 9 orang mahasiswa atau 26\% menyatakan setuju dan 25 orang mahasiswa atau 71\% sangat setuju.

Pada pernyataan "Pembelajaran dengan cara ini membuat saya bersemangat untuk belajar" pada item setuju sebanyak 8 orang mahasiswa atau 23\% dan sangat setuju sebanyak 27 orang mahasiswa atau 77\%. Hal ini menggambarkan bahwa pembelajaran dengan $C A M$ membuat mahasiswa bersemangat dalam belajar. Pada pernyataan negatif "Dengan pembelajaran ini, saya tidak berkonsentrasi dengan baik" mahasiswa yang memilih item tidak setuju sebanyak 21 orang mahasiswa atau $60 \%$ dan sangat tidak setuju sebanyak 12 orang mahasiswa atau 34\%. Dilihat dari persentase jawaban mahasiswa pada keempat item pernyataan tersebut diperoleh bahwa mahasiswa memiliki minat yang tinggi terhadap pembelajaran dengan $C A M$.

Untuk mengetahui sikap mahasiswa terhadap pembelajaran kelompok dapat dilihat tanggapan mahasiswa setuju pada pernyataan positif "Saya senang berdiskusi dengan teman-teman" dipilih oleh 12 orang mahasiswa atau 34\%, sangat setuju dipilih oleh 13 siswa atau 37\%. Untuk penyataan positif "Dengan pengelompokan seperti ini, saya terbantu dalam mempelajari materi yang diberikan" item setuju dipilih oleh 14 orang mahasiswa atau 40\% dan sangat setuju dipilih oleh 20 orang mahasiswa atau 57\%. Pernyataan negatif "Dengan belajar berkelompok, memberi kesempatan pada saya untuk bermain" item tidak setuju dipilih oleh 20 orang mahasiswa atau 57\% dan sangat tidak setuju dipilih oleh 14 orang mahasiswa atau 40\%. Pernyataan positif "Ketika ada kesulitan teman satu kelompok saling membantu" item setuju dipilih oleh 8 orang mahasiswa atau 23\% dan sangat setuju dipilih oleh 27 orang mahasiswa atau $77 \%$. Berdasarkan persentase jawaban mahasiswa pada keempat item pernyataan tersebut dapat disimpulkan bahwa mahasiswa memiliki minat yang tinggi terhadap belajar kelompok.

Sikap mahasiswa terhadap penggunaan LKM dalam pembelajaran pada pernyataan positif "LKM yang ada disusun sesuai dengan materi yang dipelajari” untuk 
item setuju dipilih oleh 18 orang mahasiswa atau 51\% dan sangat setuju dipilih oleh 14 orang mahasiswa atau 40\%, sedangkan untuk pernyataan negatif "Belajar dengan menggunakan LKM tidak dapat membantu saya dalam memahami pelajaran yang sedang dipelajari" item tidak setuju dipilih oleh 21 orang mahasiswa atau $60 \%$ dan sangat tidak setuju dipilih oleh 10 orang mahasiswa atau 29\%. Berdasarkan persentase jawaban mahasiswa pada kedua item pernyataan tersebut dapat disimpulkan bahwa mahasiswa memiliki minat yang tinggi terhadap pembelajaran menggunakan LKM. Dari hasil interpretasi terhadap indikator-indikator di atas disimpulkan bahwa sebagian besar mahasiswa memiliki sikap yang positif terhadap pembelajaran dengan $C A M$.

Selain dilihat dari angket sikap, sikap mahasiswa selama mengikuti pembelajaran dengan $C A M$ juga diperoleh dari wawancara yang dilakukan setelah postes. Mahasiswa yang diwawancarai berjumlah 5 orang. Pemilihan mahasiswa dilakukan secara acak.

Pada umumnya mahasiswa berpendapat positif terhadap pembelajaran dengan $C A M$. Mereka berpendapat bahwa pembelajaran dengan $C A M$ menarik dan menyenangkan karena terdapat banyak aktivitas di dalamnya. Melalui aktivitas tersebut mahasiswa bisa menemukan sendiri konsep-konsep pada materi dalam mata kuliah Sistem Bilangan. Aktivitas-aktivitas yang dilakukan tersebut membuat mereka lebih bersemangat dan tidak bosan dalam pembelajaran. Hal ini mungkin disebabkan karena selama ini pembelajaran matematika selalu dilakukan dengan serius, kaku, dan hanya terfokus pada dosen tanpa adanya aktivitas dari mahasiswa. Namun demikian, ada juga mahasiswa yang menganggap bahwa pembelajaran dengan $C A M$ agak membosankan karena mereka lelah dengan berbagai aktivitas yang dilakukan dalam pembelajaran. Namun, pendapat ini hanya dikemukakan oleh 1 orang mahasiswa saja dari 5 orang mahasiswa yang diwawancarai.

Mahasiswa yang merasa senang dengan pembelajaran $C A M$ pada umumnya senang dalam melakukan aktivitas-aktivitas seperti yang diperintahkan pada LKM. Melalui aktivitas-aktivitas tersebut mereka bisa lebih cepat mengerti tentang konsepkonsep materi pada mata kuliah Sistem Bilangan. Walaupun ada mahasiswa yang mengaku bosan dengan aktivitas tersebut, tetapi mereka tetap melaksanakan langkahlangkah yang diperintahkan dalam LKM hingga akhir pembelajaran.

Sebagian besar mahasiswa mengaku semakin tertarik belajar mata kuliah Sistem Bilangan dengan adanya pembelajaran $C A M$. Hal ini dikarenakan mahasiswa yang menemukan sendiri konsep-konsepnya, sehingga mahasiswa lebih cepat dalam memahami konsep-konsep tersebut. Hal ini sesuai dengan pendapat Kauchak dan Eggen mengemukakan $C A M$ adalah suatu model pembelajaran induktif yang didesain dosen, untuk membantu mahasiswa dalam mempelajari konsep dan melatih keterampilan siswa dalam mempraktekkan keterampilan berpikir analitis, kritis, kreatif 
dan lain-lain (Silitonga, 2006: 170). Bruce, dkk, berpendapat bahwa CAM menitikberatkan pada cara-cara untuk memperkuat dorongan-dorongan internal manusia dalam memahami ilmu pengetahuan, dengan cara menggali dan mengorganisasikan, serta mengembangkan bahasa untuk mengungkapkannya (Mustamin, 2005: 72).

Selain itu, mahasiswa mengaku bahwa dengan menemukan sendiri konsepkonsep tersebut mereka lebih lama dapat menyimpan dan mengingatnya dalam ingatan mereka, serta mencari tahu apa penyebab dan solusi jika mereka mendapatkan kesulitan. Dengan demikian siswa memiliki kesadaran tentang apa yang mereka rasakan dan pikirkan tentang materi yang mereka pelajari. Hal ini secara tidak langsung bersentuhan dengan kemampuan metakognitif. Metakognitif merupakan suatu proses berpikir seseorang dalam mengontrol pikirannya Amir MZ (2017) sehingga mampu melakukan refleksi diri serta memperbaikinya (Amir MZ dan Wahyudin, 2016). Hal ini senada dengan pendapat Sternberg (1999) bahwa asesmen terhadap penalaran matematis yang baik adalah asesmen yang memperhatikan aspek penalaran matematis, diantaranya aktivitas metakognitif yang terlihat ketika (1) meminta mahasiswa memformulasikan strategi untuk menyelesaikan masalah; (2) meminta mahasiswa memonitor dan mengevaluasi penyelesaian.

Mengenai kelebihan dan kekurangan model pembelajaran $C A M$, mahasiswa lebih banyak mengungkapkan kelebihan daripada kekurangannya. Kekurangan model pembelajaran ini menurut mahasiswa adalah mereka agak bosan dengan aktivitasaktivitas yang dilakukan dalam setiap pertemuan. Akan tetapi, menurut mahasiswa yang menyenangi model pembelajaran ini, aktivitas-aktivitas yang dilakukan justru sangat menarik sampai-sampai mereka merasa kekurangan waktu dalam mengerjakannya. Selain itu, dengan menemukan sendiri konsep-konsepnya membuat mahasiswa lebih cepat memahami konsep-konsep tersebut dan lebih mudah untuk mengingatnya.

Untuk lebih memaksimalkan proses pembelajaran CAM, model ini dapat dilaksanakan dengan penambahan pendekatan pembelajaran lainnya, seperti pembelajaran berkelompok kooperatif, pendekatan kontekstual, dan sebagainya. Dalam pembelajaran kooperatif setiap siswa memiliki tanggung jawab yang sama untuk keberhasilan baik untuk dirinya sendiri, maupun dalam kelompoknya (Amir MZ, dkk., 2017). Sehingga dengan modifikasi CAM dengan pembelajaran lainnya diharapkan dapat memaksimalkan proses CAM dan diharapkan berdampak pada output pembelajaran.

Secara teori, pembelajaran $C A M$ tidak memiliki syarat dalam penerapannya, model ini cocok diterapkan untuk semua kalangan, mulai dari anak-anak hingga dewasa, namun seiring dengan penelitian yang sudah dilakukan, menurut peneliti 
pengaruh pembelajaran $C A M$ terhadap kemampuan yang tingkatannya lebih tinggi akan lebih baik diterapkan, jika kemampuan pemahaman konsep dasar matematika mahasiswa sudah cukup baik, minat belajar matematika mahasiswa juga cukup baik serta jumlah mahasiswa dalam satu kelas tidak terlalu banyak agar pembelajaran lebih efektif.

\section{SIMPULAN}

Hasil penelitian menunjukkan terjadinya peningkatan kemampuan penalaran matematis mahasiswa setelah mengikuti pembelajaran $C A M$. Peningkatan ini dapat dilihat dari persentase gain ternormalisasi, dari 35 orang mahasiswa terdapat 21 orang mahasiswa (60\%) pada kategori tinggi dan sebanyak 14 orang (40\%) pada kategori sedang, dan tidak ada mahasiswa yang berada pada kategori rendah. Hal ini juga didukung oleh hasil observasi terbuka dan hasil wawancara. Berdasarkan hasil observasi, diperoleh data bahwa aktivitas pembelajaran dengan $C A M$ dapat terlaksana dengan baik selama penelitian berlangsung. Meskipun pada pertemuan-pertemuan awal terdapat beberapa kendala, namun kendala-kendala tersebut dapat diatasi dan terus dilakukan perbaikan pada tahap refleksi di setiap akhir siklus. Sikap mahasiswa terhadap pembelajaran dengan $C A M$ yang diperoleh dari skala sikap dan hasil wawancara menunjukkan bahwa sebagian besar mahasiswa memiliki sikap yang positif terhadap pembelajaran dengan $C A M$.

Penelitian ini dilaksanakan pada jenjang mahasiswa dengan jumlah 35 orang pada kajian kemampuan penalaran matematis. Untuk peneliti lainnya dapat mencoba pada tingkatan siswa dan untuk kajian tinjauan aspek kemampuan berpikir lainnya. Selain itu, model ini dapat divariasikan dengan pembelajaran lainnya seperti pembelajaran kooperatif, pendekatan metakognitif, dan lain sebagainya.

\section{REFERENSI}

Amir MZ, Zubaidah \& Wahyudin. (2016). Exploration of Metacognitive Ability at Elementry School Students in Learning Mathematics (Case Study in $1^{\text {th }}$ Grade Students of Elementray School). Journal of Innovative Technology and Education, 3 (1), 179-184.

Amir MZ, Zubaidah. (2017). Strategi Metakognitif dalam Pembelajaran Matematika. Jurnal Penelitian Pendidikan Matematika (JPPM) Vol.10 No. 1 (2017).

Amir MZ, Zubaidah. Wahyudin \& Turmudi. (2017). Metacognition Think-Aloud Strategies In Setting Cooperative Think Pair Share/Square to Develop Students' Math Problem Solving Ability. (Comparative Study on Students of 
Madrasah Tsanawiyah Boarding/non Boarding School in Pekanbaru). Advances in Social Science, Education and Humanities Research (ASSEHR), 57. Atlantis Press.

Armiati. (2011). Peningkatan Kemampuan Penalaran Matematis, Komunikasi Matematis, dan Kecerdasan Emosional Mahasiswa melalui Pembelajaran Berbasis Masalah. (Disertasi). Sekolah Pascasarjana, Universitas Pendidikan Indonesia, Bandung.

Artzt, A. F. And Yaloz, F. S. (1999). Mathematical Reasoning during Small-Group Problem Solving dalam Lee V.. Stiff dan Frances R. Curcio (edt) Developing Mathematical Reasoning in Grades K-12, 115-126. Virginia: NCTM.

Dewanto, P. S. (2002). Meningkatkan Kemampuan Berpikir Matematik Tingkat Tinggi melalui Pembelajaran dengan Pendekatan Induktif-Deduktif. Tesis pada SPs UPI Bandung: Tidak Diterbitkan

Hake, R.R. (1999).Analyzing Changel Gain Scores.[Online].Tersedia : http://www.physics.indiana.edu/ sdi/Analyzingchange-Gain.pdf

Jones, G. A. et al. (1999). Understanding Students' Probabilistics Reasoning dalam Lee V. Stiff dan Frances R. Curcio (edt). Developing Mathematical Reasoning in Grades K-12, 146-155. Virginia: NCTM.

Keraf, G. (1982). Argumen dan Narasi: Komposisi Lanjutan III. Jakarta: Gramedia

Mathematical Association of America (MAA). (2004). Undergraduate Program and Courses in the Mathematical Science. Published and Distributed by The Mathematical Association of America.

Mustamin, A. (2005). Pembelajaran Matematika Menggunakan Model Pembelajaran Pencapaian Konsep. WAKAPENDIK. 1, (1), 68-76.

National Council of Teachers of Mathematics.(2000). Principles and Standards for School Mathematics. Reston, VA: NCTM.

Russel, S. J. (1999). Mathematical Reasoning in the Elementary Grades. Dalam Lee V. Stiff dan Frances R. Curcio (edt) Developing Reasoning in Grades K-12, 1-12. Virginia: NCTM

Silitonga, M. (2006). Model Pencapaian Konsep Untuk Pengajaran Kalkulus.Jurnal Penelitian Bidang Pendidikan. 12, (2), 168-176.

Sternberg, R. J., (1999). The Nature of Mathematical Reasoning dalam Lee V. Stiff dan Frances R. Curcio (edt) Developing Mathematical Reasoning in Grades K-12, 37-44. Virginia: NCTM.

Sugiyono.(2010). Metode Penelitian Pendidikan.Bandung : Alfabeta 
Sumarmo, U. (1987). Kemampuan Pemahaman dan Penalaran Matematika Siswa Dikaitkan dengan Kemampuan Penalaran Logik Siswa dan Beberapa Unsur Proses Belajar Mengajar. Disertasi: FPS IKIP Bandung.

Turmudi.(2008). Landasan Filsafat dan Teori Pembelajaran Matematika Berparadigma Eksploratif dan Investigatif. Jakarta: Leuser Cita Pustaka.

Uno, B. H. (2008).Model pembelajaran. Jakarta: Bumi Aksara 